\title{
University Student Attitudes Towards Peer Review in EFL Writing: A Quantitative Study
}

\author{
Brett Morgan \\ Ritsumeikan University, Kusatsu, Japan \\ Bjorn Fuisting \\ Ritsumeikan University, Kusatsu, Japan \\ Jeremy White \\ Ritsumeikan University, Kusatsu, Japan
}

\begin{abstract}
This quantitative study investigates student attitudes and teacher perceptions regarding peer review in EFL writing at a Japanese university. Prior research has suggested numerous benefits from employing peer review in L2 settings, but some studies have indicated learner difficulties with peer review. A total of 125 first-year students undertook a peer review activity and completed pre- and post-activity surveys concerned with how their attitudes changed throughout the process. Results showed that students' enjoyment of writing and students' willingness to offer and accept critical feedback increased. Furthermore, students showed confidence in their peers' abilities to give feedback, but greatly doubted their own abilities. Additionally, 36 instructors completed surveys regarding their perceptions of students' peer review attitudes, showing that teachers overestimated students' discomfort in giving and receiving written feedback. Implications include the need for learner training and confidence building and greater teacher awareness of students' views towards peer review.
\end{abstract}

Peer review in writing activities has become a common feature of many L2 writing classrooms that employ a process-writing approach (Hyland \& Hyland, 2006). Peer review, which in this paper refers to the process of students editing for mistakes and giving formative feedback on other students' writing, provides writers with alternative sources of feedback to their teachers'. Theoretical support for the use of peer review is found in Vygotsky's (1978) social-constructivist learning theory, which posits that social interaction is an essential component of cognitive development, and in collaborative learning theory, which contends that learners benefit from peer interaction and dialogue and the pooling of resources to complete tasks they may find too difficult on their own (Hirvela, 1999). With the myriad pedagogical possibilities offered by the employment of peer review, many EFL / ESL programs are including peer review in their writing curriculums (Hyland \& Hyland, 2006). It is therefore prudent for educators to examine how to effectively implement this learning tool in their educational contexts.

\footnotetext{
Language Education in Asia, 2014, 5(1), 93-116.

http://dx.doi.org/10.5746/LEiA/14/V5/I1/A08/Morgan_Fuisting_White
} 
One key area of concern in adopting any language learning activity is the attitudes of students and teachers towards that activity. Research has demonstrated the link between students' motivation and their language learning success (Gardner, 1985) and noted the negative impact of affective factors such as language anxiety (Gardner, Tremblay, \& Masgoret, 1997) on L2 learning. Thus, several attitudinal questions about the use of peer review in EFL classrooms arise: Do students want to do peer review? Do students feel competent enough to do peer review? Do they feel it is an effective learning tool? Furthermore, what are teachers' perceptions of students' attitudes towards peer review? This study aims to address these questions by examining the views of Japanese university students and instructors towards peer review in writing. The researchers hope these insights can improve the way peer review can be implemented in EFL writing classes.

\section{Benefits of Peer Review}

\section{Literature Review}

Initially endorsed in L1 writing classrooms as benefiting writers by providing them with an authentic audience (Elbow, 1973), peer review has in recent decades drawn the attention of L2 researchers, who have claimed numerous linguistic, cognitive, social, and affective benefits from the use of interactive peer review activities in L2 classrooms. Among these claims are that peer review has been found to improve learners' attitudes towards writing and increase their use of metacognitive strategies (Min, 2005), develop learners' self-awareness as writers and promote a feeling of ownership of text (Tsui \& Ng, 2000), increase learner autonomy (Chaudron, 1984, as cited in Hyland \& Hyland, 2006), and aid second language acquisition (Lockhart \& Ng, 1995). While some researchers have noted that, among other difficulties, L2 peer reviewers are often unable to give useful, concrete feedback (Leki, 1990) or have argued that implementation of effective peer review is too complex to be of much use in L2 environments (Nelson \& Murphy, 1992), the body of research indicates that use of peer review in EFL classrooms can have value on several levels.

\section{Attitudes Towards Peer Review in L2 Contexts}

Some research has focused on the preferences of students for either teacher or peer feedback. Zhang's (1995) study of 81 ESL students in the United States found that they overwhelmingly preferred teacher feedback. Jacobs, Curtis, Braine, and Huang (1998) argued the two forms of feedback need not be mutually exclusive, and indeed should be seen as complementary, as their survey of $121 \mathrm{EFL}$ students in Hong Kong and Taiwan found a great majority desired peer feedback when assured of teacher feedback as well. Larger studies on peer review attitudes in other EFL contexts include Morra and Romano's (2008) study of 108 EFL teacher trainees in Argentina, which showed that, with sufficient training and a nonthreatening classroom atmosphere, students valued peer feedback. Their findings were reinforced in their interviews with two teachers, who reported noticeable positive changes in student attitudes. Although most attitudinal studies in EFL contexts have demonstrated positive student views towards peer review, some researchers (Nelson \& Carson, 1998) in ESL contexts have suggested that students from Asian cultures with a more collectivist orientation, where maintaining face is important, may find peer review threatening to group harmony and thus might be reluctant to criticize their peers. This culturally specific notion of an affective filter that impacts language acquisition is examined in the current study.

\section{Attitudes in Japan}

Several studies concerned with attitudes towards peer review in Japanese university students have been conducted. Particularly relevant to this research project is Coomber and Silver's (2010) study concerning 70 first-year economics students' preferences for either anonymous or 
face-to-face peer review, as the questions used for the current study were adopted from parts of their surveys. The authors administered four surveys designed to discover general pre- and post-activity attitudes towards peer review, as well as preferences for the two modes. Their findings suggested that after undertaking peer review, students showed an increased enjoyment of writing and a stronger belief in its effectiveness. They further concluded that students overall showed no strong preference for either mode, but that females preferred anonymous feedback. Silver and Coomber's (2011) subsequent analysis of a sample of the same students' written feedback and revisions, however, showed that anonymous feedback generated more, and more effective, feedback and greater learner uptake. This confirmed the findings of Hosack's (2003) earlier, smaller study that had a similar research focus. Taferner's (2009) study of 33 first-year students included pre- and post-activity surveys with questions about attitudes towards peer review. He found that, while maintaining skepticism towards their peers' feedback, students' opinions of peer review improved after undertaking it and that they wanted to continue using it. Hirose (2008) surveyed 15 students about their perceptions of peer review at the end of a writing course, finding that most students held positive views towards peer review, though it did not significantly improve students' writing abilities. Wakabayashi's (2008) study of 25 students confirmed that Japanese university students see some value in peer review and somewhat enjoy it, and also found evidence of a positive impact on their writing abilities.

With the exception of Coomber and Silver's (2010) study, most studies on peer review attitudes in Japan have had fairly small sample sizes, limiting the generalizability of their findings. The researchers hope the current study of 125 students can provide a broader picture of Japanese university students' attitudes towards peer review in writing. Additionally, little significant research has been conducted on the views or perceptions of EFL teachers in Asia towards peer review, an important missing element in the attempt to reach a more comprehensive understanding of the subject, and something which the researchers have tried to address with the current study and with their survey (White, Morgan, \& Fuisting, 2014) of 41 EFL teachers' attitudes towards peer review.

\section{Purpose of the Study}

The purpose of this survey-based quantitative study is to examine students' attitudes and teachers' perceptions of students' attitudes towards peer review in EFL writing activities. By conducting attitudinal surveys before and after implementation of a peer review activity, the researchers hope to gain a deeper understanding of how Japanese university students feel about giving and receiving peer review, how students view their own and their peers' abilities to conduct peer review, and how effective they feel it is as a learning activity. It is also hoped that examining teachers' perceptions of students' attitudes will further inform educators about the attitudinal and affective aspects of the peer review process.

\section{Research Questions}

The following research questions were the focus of this study:

1. What are students' attitudes towards peer review in writing and how do students' attitudes change after undertaking peer review?

2. What is the gap between teachers' perceptions of students' attitudes towards peer review and students' actual attitudes towards peer review in writing?

\section{Method}

This quantitative attitudinal study is part of a broader, multifaceted research project concerning peer review in EFL writing carried out at a private university in western Japan. Voluntary participants in the current study totaled 125 students and 36 English teachers. 


\section{Student Survey}

Population and sampling. All 125 student participants were aged 18-20 and taking intermediate or upper-intermediate level compulsory English courses in their first semester at university. There were sixty-four information science majors and 61 business majors (91 males and 34 females), all native Japanese speakers. Participants were members of six intact classes taught by the researchers. These classes were chosen for practical administrative reasons. The initial population of all classes was 140 students. However, 15 students were absent or failed to submit writing assignments; their incomplete data were not used in this study.

Instrumentation. Two paper-based instruments were used for data collection: a pre-activity survey (see Appendix A) concerning students' views towards peer review before undertaking it, and a post-activity survey (see Appendix B) concerning how their views changed after undertaking peer review. Both surveys were in English with Japanese translations. The questions on the surveys were from some of the questions used in Coomber and Silver's (2010) survey of student attitudes regarding peer review at a Japanese university.

The pre-activity survey started with demographic questions and asked if students had experienced peer review in either English or Japanese before. These were followed by nine questions concerning their enjoyment of writing, their desire to participate in peer review, their beliefs about their own English abilities and that of their peers, and their feelings about the effectiveness of peer feedback. The post-activity survey posed the same nine questions worded in the past tense, followed by nine additional questions concerned with the benefits and difficulties of doing peer review. The questions were posed as statements. A six-point Likert scale was used, with 1 indicating strong disagreement with the statement and 6 indicating strong agreement. There was no neutral option.

Data collection. The peer review activity took place in six first-year English courses (three courses each for business and information science departments) in Spring 2013. As part of the process-writing component of the courses, students were asked to submit the first draft of a writing assignment and were informed that the revision process would first include peer feedback, then teacher feedback. Due to departmental curricular differences, business students wrote an academic paragraph and information science students wrote a three-paragraph essay. On the day of submission, students received a brief explanation about peer review and their consent to participate in the study was obtained. Students were next asked to voluntarily complete an anonymous pre-activity survey concerning their views towards peer review. Students were then given an approximately 30-minute instructor-guided training session on how to edit for a) layout, paragraph and / or essay structure and content, and b) grammatical, vocabulary, spelling, and punctuation errors. Students then switched writings with a partner and spent approximately 30 minutes editing their peer's writing with a teacher-provided peer review worksheet (see Appendix C) guiding them through the process. After this, students briefly discussed their corrections face-to-face and returned the edited essays and corresponding completed worksheets to their partner. Students were asked to consider their partner's feedback and submit a second draft the following week. After submission of second drafts, students were asked to voluntarily complete an anonymous post-activity survey concerning their views towards the peer review process. Second drafts were edited by teachers, after which students submitted a final draft. 


\section{Teacher Survey}

Population and sampling. For this study, data were used from 36 teacher respondents. The teacher surveys were sent to all the English language instructors $(N=101)$ at the same private university in western Japan, and 41 returned the completed survey. Five teacher respondents did not teach intermediate or upper-intermediate level English courses, and thus were not asked to complete the survey section providing data for this facet of the study. Of the 36 participants whose data were used in this study, 25 were foreign teachers and 11 were Japanese teachers. None taught the six classes participating in the student surveys.

Instrumentation. Data used in the teacher facet of this study came from one section of a larger paper-based survey (see Appendix D) concerning teacher attitudes towards peer review. This section asked teachers of intermediate or upper-intermediate level English courses about their perceptions of their students' attitudes towards peer review. The survey consisted of eight questions regarding the same aspects asked on the student surveys and used the same six-point Likert scale. The survey was designed to discover gaps, if any, between teachers' perceptions of students' attitudes towards peer review and students' actual attitudes towards peer review.

Data collection. The teacher survey was conducted throughout the spring semester in 2013. The paper surveys were sent with an explanatory cover letter via intracampus mail, and respondents were requested to return completed surveys in the same way to ensure anonymity.

\section{Ethics and Consent}

For the student and teacher surveys, researchers provided explanations of the purpose of the study and of steps taken to ensure confidentiality of participants. Student participants were informed, verbally and in writing, that participation was voluntary and would not affect course grades, and written consent forms (see Appendix E) with Japanese translations were obtained. Teacher participants were assured of anonymity and informed that submitting the completed survey indicated their consent.

\section{Description of the Sample}

\section{Results}

In total, 125 students and 36 instructors participated in the surveys. Demographic characteristics of students and instructors can be found in Tables F1 and F2 in Appendix F.

\section{Descriptive Statistics}

The results were analyzed in three ways. Firstly, the changes in attitude to peer review were tracked by comparing the answers to questions $(Q)$ 1-9 on the post-activity survey with those given on the pre-activity survey. Secondly, the answers from the additional nine questions in the post-activity survey were analyzed. Finally, the post-activity survey answers to Q1-9 were compared with those given by the teachers to Q1-8 to detect any differences in perceived student attitudes to actual student attitudes. Descriptive statistics relevant to each section, including the questions, can be found in Tables 1-4. 
Table 1

Descriptive Statistics, Student Pre-Activity Survey Q1-9

\begin{tabular}{|l|c|c|c|c|c|c|c|}
\hline \multicolumn{1}{|c|}{ Question } & $n$ & Mean & Mode & Median & $\begin{array}{c}\text { Low- } \\
\text { High }\end{array}$ & Range & $S D$ \\
\hline 1. I enjoy writing in English. & 125 & 3.44 & 4 & 3 & $1-6$ & 6 & 1.1 \\
\hline $\begin{array}{l}\text { 2. Writing comments on my classmate's } \\
\text { work is not a problem. }\end{array}$ & 125 & 4.08 & 4 & 4 & $1-6$ & 6 & 1.09 \\
\hline 3. I want to show my work to my classmate. & 125 & 2.6 & 3 & 3 & $1-5$ & 5 & 0.89 \\
\hline $\begin{array}{l}\text { 4. I want to read my classmate's work. } \\
\text { 5. My English level is good enough to help } \\
\text { my classmate improve his / her writing. }\end{array}$ & 125 & 3.91 & 4 & 4 & $1-6$ & 6 & 1 \\
\hline $\begin{array}{l}\text { 6. My classmate's English level is good } \\
\text { enough to help me improve my writing. }\end{array}$ & 125 & 4.26 & 4 & 4 & $1-6$ & 6 & 1.01 \\
\hline $\begin{array}{l}\text { 7. I feel uncomfortable writing on my } \\
\text { classmate's work. }\end{array}$ & 125 & 3.26 & 3 & 3 & $1-6$ & 6 & 1.14 \\
\hline $\begin{array}{l}\text { 8. Negative feedback helps me improve my } \\
\text { work. }\end{array}$ & 125 & 4.99 & 5 & 5 & $1-6$ & 6 & 0.81 \\
\hline $\begin{array}{l}\text { 9. Positive feedback helps me improve my } \\
\text { work. }\end{array}$ & 125 & 4.74 & 5 & 5 & $1-6$ & 6 & 0.88 \\
\hline
\end{tabular}

Note. 1 = strongly disagree, 2 = disagree, 3 = somewhat disagree, 4 = somewhat agree, $5=$ agree, $6=$ strongly agree.

Table 2

Descriptive Statistics, Student Post-Activity Survey Q1-9

\begin{tabular}{|l|c|c|c|c|c|c|c|}
\hline \multicolumn{1}{|c|}{ Question } & $n$ & Mean & Mode & Median & $\begin{array}{c}\text { Low- } \\
\text { High }\end{array}$ & Range & $S D$ \\
\hline 1. I enjoy writing in English. & 125 & 3.7 & 4 & 4 & $1-6$ & 6 & 1.17 \\
\hline $\begin{array}{l}\text { 2. Writing comments on my classmate's } \\
\text { work was not a problem. }\end{array}$ & 125 & 4.25 & 5 & 4 & $1-6$ & 6 & 1.13 \\
\hline 3. I liked showing my work to my classmate. & 125 & 2.94 & 3 & 3 & $1-6$ & 6 & 1.02 \\
\hline 4. I liked reading my classmate's work. & 125 & 4.09 & 4 & 4 & $1-6$ & 6 & 1.07 \\
\hline $\begin{array}{l}\text { 5. My English level is good enough to help } \\
\text { my classmate improve his / her writing. }\end{array}$ & 125 & 2.47 & 2 & 2 & $1-5$ & 5 & 0.99 \\
\hline $\begin{array}{l}\text { 6. My classmate's English level is good } \\
\text { enough to help me improve my writing. }\end{array}$ & 125 & 4.38 & 5 & 5 & $1-6$ & 6 & 1.05 \\
\hline $\begin{array}{l}\text { 7. I felt uncomfortable writing on my } \\
\text { classmate's work. }\end{array}$ & 125 & 2.98 & 3 & 3 & $1-6$ & 6 & 1.19 \\
\hline $\begin{array}{l}\text { 8. Negative feedback helped me improve } \\
\text { my work. }\end{array}$ & 125 & 4.69 & 5 & 5 & $1-6$ & 6 & 0.79 \\
\hline $\begin{array}{l}\text { 9. Positive feedback helped me improve my } \\
\text { work. }\end{array}$ & 124 & 4.51 & 4 & 4 & $1-6$ & 6 & 0.84 \\
\hline
\end{tabular}

Note. 1 = strongly disagree, 2 = disagree, $3=$ somewhat disagree, $4=$ somewhat agree, $5=$ agree, $6=$ strongly agree. 
Table 3

Descriptive Statistics, Student Post-Activity Survey Q10-18

\begin{tabular}{|l|c|c|c|c|c|c|c|}
\hline \multicolumn{1}{|c|}{ Question } & $n$ & Mean & Mode & Median & $\begin{array}{c}\text { Low- } \\
\text { High }\end{array}$ & Range & $S D$ \\
\hline $\begin{array}{l}\text { 10. My classmate's written feedback helped } \\
\text { me improve my work. }\end{array}$ & 125 & 4.71 & 5 & 5 & $1-6$ & 6 & 0.87 \\
\hline $\begin{array}{l}\text { 11. My classmate's oral feedback helped } \\
\text { me improve my work. }\end{array}$ & 125 & 4.67 & 5 & 5 & $2-6$ & 5 & 0.87 \\
\hline $\begin{array}{l}\text { 12. It was useful to know who wrote the } \\
\text { comments on my writing. }\end{array}$ & 125 & 3.79 & 4 & 4 & $1-6$ & 6 & 1.13 \\
\hline $\begin{array}{l}\text { 13. I felt like my classmate was criticizing } \\
\text { me. }\end{array}$ & 125 & 1.97 & 2 & 2 & $1-5$ & 5 & 0.86 \\
\hline $\begin{array}{l}\text { 14. I think my written comments were useful } \\
\text { for my classmate. }\end{array}$ & 125 & 3.41 & 4 & 4 & $1-6$ & 6 & 0.92 \\
\hline $\begin{array}{l}\text { 15. I think my oral comments were useful } \\
\text { for my classmate. }\end{array}$ & 125 & 3.51 & 4 & 4 & $1-6$ & 6 & 0.92 \\
\hline $\begin{array}{l}\text { 16. It was easy to find something to say } \\
\text { about my classmate's work. }\end{array}$ & 125 & 3.14 & 3 & 3 & $1-6$ & 6 & 1.13 \\
\hline $\begin{array}{l}\text { 17. Giving negative feedback was difficult } \\
\text { for me. }\end{array}$ & 125 & 3.11 & 3 & 3 & $1-6$ & 6 & 1.13 \\
\hline $\begin{array}{l}\text { 18. I worried about hurting my classmate's } \\
\text { feelings. }\end{array}$ & 125 & 2.5 & 3 & 2 & $1-6$ & 6 & 0.98 \\
\hline
\end{tabular}

Note. 1 = strongly disagree, 2 = disagree, 3 = somewhat disagree, 4 = somewhat agree, 5 = agree, $6=$ strongly agree.

Table 4

Descriptive Statistics, Teacher Survey Q1-8

\begin{tabular}{|l|c|c|c|c|c|c|c|}
\hline \multicolumn{1}{|c|}{ Question } & $n$ & Mean & Mode & Median & $\begin{array}{c}\text { Low- } \\
\text { High }\end{array}$ & Range & $S D$ \\
\hline 1. My students enjoy writing. & 36 & 3.75 & 4 & 4 & $2-5$ & 4 & 0.92 \\
\hline $\begin{array}{l}\text { 2. Writing comments on classmates work is } \\
\text { NOT a problem for my students. }\end{array}$ & 36 & 3.36 & 4 & 4 & $1-6$ & 6 & 1.16 \\
\hline $\begin{array}{l}\text { 3. My students want to show their written } \\
\text { work to their classmates. }\end{array}$ & 36 & 3.22 & 3 & 3 & $1-5$ & 5 & 0.97 \\
\hline $\begin{array}{l}\text { 4. My students want to read their } \\
\text { classmates' work. }\end{array}$ & 36 & 3.83 & 4 & 4 & $1-5$ & 5 & 0.9 \\
\hline $\begin{array}{l}\text { 5. My students' English level is good } \\
\text { enough to help their classmates' work. }\end{array}$ & 36 & 3.78 & 4 & 4 & $1-6$ & 6 & 1.18 \\
\hline $\begin{array}{l}\text { 6. My students feel uncomfortable writing } \\
\text { on their classmates work. }\end{array}$ & 35 & 3.71 & 4 & 4 & $1-6$ & 5 & 1.14 \\
\hline $\begin{array}{l}\text { 7. My students believe that negative } \\
\text { feedback helps them improve their work. }\end{array}$ & 35 & 4 & 4 & 4 & $1-6$ & 6 & 1.22 \\
\hline $\begin{array}{l}\text { 8. My students believe that positive } \\
\text { feedback helps them improve their work. }\end{array}$ & 35 & 4.43 & 4 & 4 & $3-6$ & 4 & 0.73 \\
\hline
\end{tabular}

Note. 1 = strongly disagree, 2 = disagree, 3 = somewhat disagree, 4 = somewhat agree, $5=$ agree, $6=$ strongly agree. 


\section{T-Test}

To check if the changes in answers for the first nine questions of the student post-activity survey could be attributed to chance, a t-test was performed. The results are shown in Table G1 in Appendix G. The changes in answers to Q1, Q3, Q5, and Q7-9 were statistically significant.

\section{Pre-Activity and Post-Activity Surveys Q1-9}

Table 5 shows how many students chose each answer on the six-point Likert scale as a percentage. Columns Disagree and Agree show the aggregated percentages of respondents who disagreed (Answers 1, 2, and 3) and agreed (Answers 4, 5, and 6) with the statements.

Table 5

Changes in Attitudes, Pre- and Post-Activity Surveys Q1-9

\begin{tabular}{|c|c|c|c|c|c|c|c|c|c|}
\hline $\mathrm{Q}$ & Survey & 1 & 2 & 3 & 4 & 5 & 6 & Disagree & Agree \\
\hline \multirow{2}{*}{1} & Pre & 2.4 & 19.2 & 28.8 & 34.4 & 12 & 3.2 & 50.4 & 49.6 \\
\cline { 2 - 11 } & Post & 4 & 9.6 & 28.8 & 32.8 & 19.2 & 5.6 & 42.4 & 57.6 \\
\hline \multirow{2}{*}{2} & Pre & 2.4 & 6.4 & 16 & 36.8 & 32.8 & 5.6 & 24.8 & 75.2 \\
\cline { 2 - 11 } & Post & 3.2 & 3.2 & 16 & 30.4 & 37.6 & 9.6 & 22.4 & 77.6 \\
\hline \multirow{2}{*}{3} & Pre & 13.6 & 26.4 & 47.2 & 12 & 0.8 & 0 & 87.2 & 12.8 \\
\cline { 2 - 11 } & Post & 8.8 & 20 & 47.2 & 18.4 & 4 & 1.6 & 76 & 24 \\
\hline \multirow{2}{*}{4} & Pre & 2.4 & 5.6 & 19.2 & 48 & 20.8 & 4 & 27.2 & 72.8 \\
\cline { 2 - 11 } & Post & 2.4 & 4.8 & 16 & 43.2 & 25.6 & 8 & 23.2 & 76.8 \\
\hline \multirow{2}{*}{5} & Pre & 24.8 & 45.6 & 22.4 & 7.2 & 0 & 0 & 92.8 & 7.2 \\
\cline { 2 - 10 } & Post & 18.4 & 33.6 & 31.2 & 16 & 0.8 & 0 & 83.2 & 16.8 \\
\hline \multirow{2}{*}{6} & Pre & 1.6 & 5.6 & 8 & 41.6 & 36 & 7.2 & 15.2 & 84.8 \\
\cline { 2 - 10 } & Post & 3.2 & 1.6 & 9.6 & 35.2 & 40.8 & 9.6 & 14.4 & 85.6 \\
\hline \multirow{2}{*}{7} & Pre & 8 & 14.4 & 36.8 & 28 & 10.4 & 2.4 & 59.2 & 40.8 \\
\cline { 2 - 10 } & Post & 11.2 & 21.6 & 37.6 & 20 & 6.4 & 3.2 & 70.4 & 29.6 \\
\hline \multirow{2}{*}{8} & Pre & 0.8 & 0 & 1.6 & 20.8 & 50.4 & 26.4 & 2.4 & 97.6 \\
\cline { 2 - 10 } & Post & 0.8 & 0 & 0.8 & 41.6 & 41.6 & 15.2 & 1.6 & 98.4 \\
\hline \multirow{2}{*}{9} & Pre & 0.8 & 0.8 & 3.2 & 32.8 & 44 & 18.4 & 4.8 & 95.2 \\
\cline { 2 - 9 } & Post & 0 & 1.6 & 6.5 & 42.7 & 37.9 & 11.3 & 8.1 & 91.9 \\
\hline
\end{tabular}

Note. 1 = strongly disagree, 2 = disagree, 3 = somewhat disagree, $4=$ somewhat agree, $5=$ agree, $6=$ strongly agree.

\section{Post-Activity Survey Q10-18}

Table 6 shows the answers to the additional nine statements concerned with the benefits and difficulties of doing peer review asked in the post-activity survey as percentages; it also shows the aggregated percentages of disagreement and agreement. 


\section{Table 6}

\section{Attitudes, Post-Activity Survey Q10-18}

\begin{tabular}{|c|c|c|c|c|c|c|c|c|}
\hline $\mathrm{Q}$ & 1 & 2 & 3 & 4 & 5 & 6 & Disagree & Agree \\
\hline 10 & 0.8 & 0.8 & 2.4 & 36 & 42.4 & 17.6 & 4 & 96 \\
\hline 11 & 0 & 1.6 & 4 & 37.6 & 39.2 & 17.6 & 5.6 & 94.4 \\
\hline 12 & 4 & 8.8 & 20 & 44 & 17.6 & 5.6 & 32.8 & 67.2 \\
\hline 13 & 33.6 & 40 & 23.2 & 2.4 & 0.8 & 0 & 96.8 & 3.2 \\
\hline 14 & 3.2 & 11.2 & 35.2 & 44 & 4.8 & 1.6 & 49.6 & 50.4 \\
\hline 15 & 2.4 & 9.6 & 32.8 & 47.2 & 5.6 & 2.4 & 44.8 & 55.2 \\
\hline 16 & 4.8 & 26.4 & 33.6 & 23.2 & 9.6 & 2.4 & 64.8 & 35.2 \\
\hline 17 & 8 & 22.4 & 31.2 & 28.8 & 8 & 1.6 & 61.6 & 38.4 \\
\hline 18 & 15.2 & 35.2 & 37.6 & 8.8 & 2.4 & 0.8 & 88 & 12 \\
\hline
\end{tabular}

Note. 1 = strongly disagree, 2 = disagree, 3 = somewhat disagree, 4 = somewhat agree, 5 = agree, $6=$ strongly agree.

\section{Teachers' Perceptions of Students' Attitudes}

Table 7 shows the teachers' perceptions of students' attitudes towards peer review as percentages, as well as the aggregated percentages of disagreement and agreement.

Table 7

Teachers' Perceptions of Students' Attitudes Towards Peer Review

\begin{tabular}{|c|c|c|c|c|c|c|c|c|}
\hline $\mathrm{Q}$ & 1 & 2 & 3 & 4 & 5 & 6 & Disagree & Agree \\
\hline 1 & 0 & 11.1 & 25 & 41.7 & 22.2 & 0 & 36.1 & 63.9 \\
\hline 2 & 2.8 & 27.8 & 16.7 & 38.9 & 11.1 & 2.8 & 47.2 & 52.8 \\
\hline 3 & 2.8 & 19.4 & 41.7 & 25 & 11.1 & 0 & 63.9 & 36.1 \\
\hline 4 & 2.8 & 2.8 & 25 & 47.2 & 22.2 & 0 & 30.6 & 69.4 \\
\hline 5 & 2.8 & 16.7 & 13.9 & 36.1 & 27.8 & 2.8 & 33.3 & 66.7 \\
\hline 6 & 5.7 & 11.4 & 14.3 & 42.9 & 25.7 & 0 & 31.4 & 68.6 \\
\hline 7 & 2.9 & 14.3 & 8.6 & 34.3 & 34.3 & 5.7 & 25.7 & 74.3 \\
\hline 8 & 0 & 0 & 8.6 & 45.7 & 40 & 5.7 & 8.6 & 91.4 \\
\hline
\end{tabular}

Note. 1 = strongly disagree, 2 = disagree, 3 = somewhat disagree, 4 = somewhat agree, 5 = agree, $6=$ strongly agree.

\section{Discussion}

Some of the students' attitudes towards peer review in writing changed after undertaking it. Comparing the aggregated percentages in Table 5 indicates the shift in perceptions of the statements from disagreement on the pre-activity survey to agreement on the post-activity survey. In the post-activity survey (Appendix B), 8\% or more had such changes on Q1, Q3, Q5, and Q7. This is also reflected in the changes in the mean score (see Tables 1 and 2). Q8 and Q9 also had large changes in mean scores, but for those statements, the changes in students' opinions were mainly within the category of Agree, i.e., moving from "strongly agree" to "agree" rather than changing from "slightly agree" to "slightly disagree." More students enjoyed writing and wanted to show their work to their classmates than prior to peer review $(+8 \%$ and $+11.2 \%)$. Whilst the clear majority $(83.2 \%)$ still did not think their English level was good enough to help their classmates improve their writing, the percentage of students who believed they had the ability to help their classmates improve their writing more than doubled from $7.2 \%$ to $16.8 \%$. Additionally, $11.2 \%$ less students felt uncomfortable writing on their classmates' work after having undergone peer review. 
The post-activity survey (Appendix B) also highlighted additional attitudes towards peer review. In Table 6, Q10, Q11, Q13 and Q18, had aggregated percentages of more than 88\% of students either agreeing or disagreeing with the statements. The students overwhelmingly thought that their classmates' written and oral feedback were helpful (96\% and 94.4\%), whilst only half said the same about their own written and oral comments (50.4\% and 55.2\%). Almost all (96.8\%) students did not feel criticized by the feedback they received, and most $(88 \%)$ did not worry about hurting their classmates' feelings when giving feedback during peer review. The students' attitudes and the trend in changes after undertaking peer review found in this study confirm the findings in Coomber and Silver (2010). Additionally, the findings of this study support the generally positive attitudes towards peer review that have been reported in prior research (Hirose, 2008; Morra \& Romano, 2008; Wakabayashi, 2008) with EFL students.

Gaps in teachers' perception of students' attitudes towards peer review and students' actual attitudes were also found. Comparing the teachers' perceptions of the students' attitudes (Table 7) to the students' actual attitudes in the post-activity survey (Table 5), four statements (Q2, Q5, Q6 and Q7 in Table 7, compared to Q2, Q5, Q7 and Q8 in Table 5) had an 18\% or higher difference. Whilst only $52.8 \%$ of teachers believed that students did not have a problem writing comments on their classmates' work, $77.6 \%$ of students stated that it was not a problem. In total, $66.7 \%$ of teachers believed the students' English level was good enough to help improve their classmates' writing. In contrast, only $16.8 \%$ of students agreed about their own level being good enough, but $85.6 \%$ of students thought that their peers' language level was up to the task (Q6 in Table 5). A much larger share of teachers perceived the students to feel uncomfortable writing on their classmates' work than was actually the case (68.6\% vs. $29.6 \%)$. Whilst almost all students (98.4\%) thought that negative feedback was helpful, only $74.3 \%$ of teachers thought students would think so.

\section{Conclusion}

Confirming what many studies in L2 contexts have found, students generally find value in peer review. They believe that the oral and written feedback they receive from their peers is beneficial to improving their writing. However, they doubt that their own ability to give feedback is good enough to help their peers. They are hesitant to show their own work but want to read their peers' writing. Although they have some difficulty in knowing what to write on peers' papers, they don't feel like they are criticizing or being criticized, and they feel comfortable writing on their peers' papers. This somewhat contradicts the notion of a facesaving affective filter for Japanese learners, at least for this age group. It is also clear that the teachers overestimate students' level of discomfort in actually giving written feedback, while they underestimate students' beliefs in negative feedback. One clear implication from this study is that students might benefit from some confidence-building measures in the peer review process, such as sufficient training and reassuring teacher feedback before final evaluation of writing. In general, teachers being aware of students' attitudes could lead to better implementation of peer review in EFL writing programs.

\section{Limitations and Suggestions for Further Research}

The results of this study could be applicable to other institutions in Japan and could possibly be relevant to other EFL contexts in Asia. However, all student participants belonged to the business and information science departments, and $72.8 \%$ of them were male; thus students with different majors or students at institutes with a larger female student body might not share the same attitudes. In addition, this study only collected reported attitudes and did not analyze the quantity, quality, or effectiveness of peer feedback. It also relied solely on statistical analysis, and the subject could benefit from more in-depth qualitative data. 


\section{Author Note}

Brett Morgan, College of Information Science and Engineering, Ritsumeikan University, Kusatsu, Japan; Bjorn Fuisting, College of Business Administration and Management, Ritsumeikan University, Kusatsu, Japan; Jeremy White, College of Information Science and Engineering, Ritsumeikan University, Kusatsu, Japan.

This paper is part of a multifaceted study. Other parts of the data set have been published in White, Morgan, \& Fuisting (2014). The authors would like to thank all the students and colleagues who filled out the surveys and the people who gave feedback on the design and assisted in various ways throughout the process, especially Richard Silver and Matthew Coomber for giving full access to their survey data and Yuko Shimizu for giving guidance in statistical analysis.

Correspondence concerning this article should be addressed to Brett Morgan, College of Information Science and Engineering, Ritsumeikan University, 1-1-1 Noji-higashi, Kusatsu, Shiga Prefecture, 525-8577 Japan. E-mail: morgan@fc.ritsumei.ac.jp 


\section{References}

Coomber, M., \& Silver, R. (2010). The effect of anonymity in peer review. In A. M. Stoke (Ed.), JALT2009 Conference Proceedings. Tokyo, Japan: JALT.

Elbow, P. (1973). Writing without teachers. New York, NY: Oxford University Press.

Gardner, R. C. (1985). Social psychology and second language learning: The role of attitudes and motivation. London, England: Edward Arnold.

Gardner, R. C., Tremblay, P. F., \& Masgoret, A.-M. (1997). Towards a full model of second language learning: An empirical investigation. The Modern Language Journal, 81(3), 344-362. http://dx.doi.org/10.1111/j.1540-4781.1997.tb05495.x

Hirose, K. (2008). Peer feedback in L2 English writing instruction. In K. Bradford Watts, T. Muller, \& M. Swanson (Eds.), JALT2007 Conference Proceedings. Tokyo, Japan: JALT.

Hirvela, A. (1999). Collaborative writing instruction and communities of readers and writers. TESOL Journal, 8(2), 7-12. http://dx.doi.org/10.1002/j.1949-3533.1999.tb00169.x

Hosack, I. (2003). The effects of anonymous feedback on Japanese university students' attitudes towards peer review. Ritsumeikanhougaku Bessatsu, 1, 297-322.

Hyland, K., \& Hyland, F. (2006). Feedback on second language students' writing. Language Teaching, 39(02), 83-101. http://dx.doi.org/10.1017/S0261444806003399

Jacobs, G. M., Curtis, A., Braine, G., \& Huang, S.-Y. (1998). Feedback on student writing: Taking the middle path. Journal of Second Language Writing, 73), 307-317. http://dx.doi.org/10.1016/S1060-3743(98)90019-4

Leki, I. (1990). Potential problems with peer responding in ESL writing classes. CATESOL Journal, 3(1), 5-19.

Lockhart, C., \& Ng, P. (1995). Analyzing talk in ESL peer response groups: Stances, functions, and content. Language Learning, 45(4), 605-651. http://dx.doi.org/10.1111/j.14671770.1995.tb00456.x

Min, H.-T. (2005). Training students to become successful peer reviewers. System, 33(2), 293308. http://dx.doi.org/10.1016/j.system.2004.11.003

Morra, A. M., \& Romano, M. E. (2008). University students' reactions to guided peer feedback of EAP compositions. Journal of College Literacy and Learning, 35, 19-30.

Nelson, G. L., \& Carson, J. G. (1998). ESL students' perceptions of effectiveness in peer response groups. Journal of Second Language Writing, オ2), 113-131. http://dx.doi.org/10.1016/S1060-3743(98)90010-8

Nelson, G. L., \& Murphy, G. M. (1992). An L2 writing group: Task and social dimensions. Journal of Second Language Writing, 1(3), 171-193. http://dx.doi.org/10.1016/10603743(92)90002-7

Silver, R., \& Coomber, M. (2011). How anonymity affects feedback in the peer review process. KOTESOL Proceedings 2010, 299-308. Available at http://www.koreatesol.org/sites/default/files/pdf_publications/KOTESOLProceeds2010web.pdf

Taferner, R. H. (2009). Attitudes toward peer collaboration within the EFL writing context in Japan. In A. M. Stoke (Ed.), JALT2008 Conference Proceedings. Tokyo, Japan: JALT.

Tsui, A. B. M., \& Ng, M. (2000). Do secondary L2 writers benefit from peer comments? Journal of Second Language Writing, 9(2), 147-170. http://dx.doi.org/10.1016/S10603743(00)00022-9

Vygotsky, L. (1978). Mind in society. Cambridge, MA: Harvard University Press.

Wakabayashi, R. (2008). The effect of peer feedback on EFL writing: Focusing on Japanese university students. OnCue Journal, 2(2), 92-110.

White, J., Morgan, B., \& Fuisting, B. (2014). Peer review in EFL writing: Teacher attitudes. Perspectives, 22(2), 20-27. 
Zhang, S. (1995). Reexamining the affective advantage of peer feedback in the ESL writing class. Journal of Second Language Writing, 4(3), 209-222.

http://dx.doi.org/10.1016/1060-3743(95)90010-1 


\section{Appendix A \\ Student Pre-Activity Survey}

\section{Explanation of Peer Review Research - 「Peer Review」研究の説明}

\section{What is peer review?}

Your peers are your classmates. Peer review is when you read another classmate's work and you write comments on their paper. You write comments on their paper to help them improve their writing. You should write both positive and negative comments, but try to write comments that will help your classmate. Sometimes you talk to them about their writing after you have read it.

$\lceil$ peer」とは、「能力・経験・年齢などが同等の人」という意味です。つまり、クラスメートは皆 「peers」になります。「peer review」とは同じレベルの人による評価を意味します。今回皆の英語 の作文力を上げるために、このクラスで「peer review」をしてみたいと思います。このクラスで行 う「peer review」とは、クラスメートの書いた作文を互いに読み、評価しあうことを意味します。 まず長所と短所がどこにあるかを考えながらクラスメートの作文を読みます。スペルや文法の間違い をしていないか、不要な文が書かれていないか、分かりにくいところはないか、あるいは構成や例が 分かりやすい、「topic sentence」、「concluding sentence」が明確に書かれている、「support」 の仕方が上手など直接英語、あるいは日本語でコメントを書いてください。それらのコメントを、作 文を書いた本人に口頭で説明をしてもらうこともあります。

This survey is being carried out in order to help us find the best way to help you write better. Please fill out the questionnaire honestly in English or Japanese. It is entirely anonymous and it does not count towards your final assessment.

このアンケートの目的はライティング力の向上をどうすれば教師が助ければよいかを見つけることに あります。匿名で成績評価には一切関係ありませんので、英語もしくは日本語で自由な意見を書いて ください。

Male Female
男 $\quad$ 女

\section{Peer Review Pre-Activity Survey}

a) Have you done peer review in Japanese before?

日本語で peer review したことがありますか。

b) Have you done peer review in English before?

英語で peer review したことがありますか。

c) Have you been abroad for more than six months?

六ヶ月以上外国に住んだことがありますか。
Yes / No

はい・いいえ

Yes / No

はい・いいえ

Yes / No

はい・いいえ

If yes, for how long:

はいを選んだ人 期間:

If yes, in which country:

はいを選んだ人 国:

If yes, between what ages:

はいを選んだ人 何歳から何歳まで: 


\begin{tabular}{|c|c|c|c|c|c|}
\hline $\begin{array}{c}1 \\
\text { Strongly } \\
\text { disagree } \\
\text { 全くそう } \\
\text { 思わない }\end{array}$ & $\begin{array}{c}2 \\
\text { Disagree } \\
\text { そう思わない }\end{array}$ & $\begin{array}{c}3 \\
\text { Somewhat } \\
\text { disagree } \\
\text { どちらかといえ } \\
\text { ばそう思わない }\end{array}$ & $\begin{array}{c}4 \\
\text { Somewhat } \\
\text { agree } \\
\text { どちらかといえ } \\
\text { ばそう思う }\end{array}$ & $\begin{array}{c}5 \\
\text { Agree } \\
\text { そう思う }\end{array}$ & $\begin{array}{c}6 \\
\text { Strongly agree } \\
\text { とてもそう思う }\end{array}$ \\
\hline
\end{tabular}

1) I enjoy writing in English.

英語で書くのが好きだ。

$\begin{array}{llllll}1 & 2 & 3 & 4 & 5 & 6\end{array}$

2) Writing comments on my classmate's work is not a problem.

クラスメートの作文にコメントを書くのは特に問題ではない。

$\begin{array}{llllll}1 & 2 & 3 & 4 & 5\end{array}$

3) I want to show my work to my classmate.

自分の作文をクラスメートに見せたい。

$\begin{array}{llllll}1 & 2 & 3 & 4 & 5 & 6\end{array}$

4) I want to read my classmate's work.

クラスメートの作文を読みたい。

$\begin{array}{llllll}1 & 2 & 3 & 4 & 5 & 6\end{array}$

5) My English level is good enough to help my classmate improve his / her writing. 私にクラスメートの作文のアドバイスができるほどの英語力があるとは思う。

$\begin{array}{llllll}1 & 2 & 3 & 4 & 5\end{array}$

6) My classmate's English level is good enough to help me improve my writing. クラスメートには私の作文のアドバイスができるほどの英語力があるとは思う。

$\begin{array}{llllll}1 & 2 & 3 & 4 & 5\end{array}$

7) I feel uncomfortable writing on my classmate's work.

クラスメートの作文にコメントを書くことに抵抗がある。

$\begin{array}{llllll}1 & 2 & 3 & 4 & 5\end{array}$

8) Negative feedback helps me improve my work.

悪い点を指摘されることで作文力を上げることができる

$\begin{array}{llllll}1 & 2 & 3 & 4 & 5\end{array}$

9) Positive feedback helps me improve my work.

良い点を指摘されることで作文力を上げることができる。
1
2
3
4 


\section{Appendix B}

Student Post-Activity Survey

Male Female

男・ 女

Peer Review Post-Activity Survey

\begin{tabular}{|c|c|c|c|c|c|}
\hline 1 & 2 & 3 & 4 & 5 & 6 \\
$\begin{array}{c}\text { Strongly } \\
\text { disagree }\end{array}$ & Disagree & そomewhat & Somewhat & Agree & Strongly agree \\
全くそう思わない & disagree & agree & そう思う & とてもそう思う \\
思わない & & どちらかといえ & どちらかといえ & & \\
\hline
\end{tabular}

1) I enjoy writing in English.

英語で書くのが好きだ。
1
3
4
5
6

2) Writing comments on my classmate's work was not a problem.

クラスメートの作文にコメントを書くのは特に問題ではなかった。
1
2
$3 \quad 4$
5
6

3) I liked showing my work to my classmate.

自分の作文をクラスメートに見せるのが好きだった。

$\begin{array}{llllll}1 & 2 & 3 & 4 & 5 & 6\end{array}$

4) I liked reading my classmate's work.

クラスメートの作文を読むのが好きだった。

$\begin{array}{llllll}1 & 2 & 3 & 4 & 5 & 6\end{array}$

5) My English level is good enough to help my classmate improve his / her writing.

私にクラスメートの作文のアドバイスができるほどの英語力があるとは思う。

$\begin{array}{llllll}1 & 2 & 3 & 4 & 5\end{array}$

6) My classmate's English level is good enough to help me improve my writing.

クラスメートには私の作文のアドバイスができるほどの英語力があるとは思う。
1
2
3
4
5
6

7) I felt uncomfortable writing on my classmate's work.
クラスメートの作文にコメントを書くことに抵抗があった。
$1 \quad 2 \quad 3 \quad 4$
6

8) Negative feedback helped me improve my work.

悪い点を指摘されることで作文力を上げることができた。
1
3
4
5
6

9) Positive feedback helped me improve my work.

良い点を指摘されることで作文力を上げることができた。
1
2
3
4
5
6 
10) My classmate's written feedback helped me improve my work.

クラスメートが書いてくれたコメントのおかげで作文をより改善することができた。
1
2
3
4
5
6

11) My classmate's oral feedback helped me improve my work.

クラスメートが言ってくれたコメントのおかげで作文をょり改善することができた。
1
2
3
4
5
6

12) It was useful to know who wrote the comments on my writing. 誰が書いてくれたコメントかが分かるので良い。
1
2
3
4
5
6

13) I felt like my classmate was criticizing me.

クラスメートのコメントに非難される感じがあった。

$\begin{array}{llllll}1 & 2 & 3 & 4 & 5 & 6\end{array}$

14) I think my written comments were useful for my classmate.

私が書いたコメントはクラスメートに役に立つと思う。
1
2
4
5
6

15) I think my oral comments were useful for my classmate.

私が言ったコメントはクラスメートに役に立つと思う。

$\begin{array}{llllll}1 & 2 & 3 & 4 & 5 & 6\end{array}$

16) It was easy to find something to say about my classmate's work.

クラスメートの作文について何かコメントを考えるのは難しくなかった。

$\begin{array}{llllll}1 & 2 & 3 & 4 & 5 & 6\end{array}$

17) Giving negative feedback was difficult for me.

悪い点は指摘し難い感じがあった。

$\begin{array}{llllll}1 & 2 & 3 & 4 & 5 & 6\end{array}$

18) I worried about hurting my classmate's feelings.

クラスメートの感情を害する恐れがあった。

$\begin{array}{lllllll}1 & 2 & 3 & 4 & 5 & 6\end{array}$ 


\section{Appendix C \\ Peer Review Worksheets}

Peer Review Worksheet - Paragraph

Author Reviewer

Please read your classmate's paragraph and answer the following questions. For each question circle Good, Fair, or Needs Revision and write a comment.

\section{Layout}

Is the layout correct?

Good Fair Needs Revision

Comment:

\section{Paragraph Structure}

Is there a topic sentence with a clear main idea?

Good Fair Needs Revision

Comment:

Do all supporting sentences develop the main idea?

Good Fair Needs Revision

Comment:

Is there a good concluding sentence?

Good Fair Needs Revision

Comment:

\section{Grammar, Vocabulary, and Spelling}

Read the paragraph again and look for grammar, vocabulary, punctuation, and spelling mistakes. Ask for help if you need it. Make some corrections on your classmate's paper.

Please write any other comments about your partner's paragraph. 


\section{Peer Review Worksheet - Essay}

Author Reviewer

Please read your classmate's essay and answer the following questions. For each question circle Good, Fair, or Needs Revision and write a comment.

\section{Layout}

Is the layout correct?

Good Fair Needs Revision

Comment:

\section{Essay and Paragraph Structure}

Look at Paragraph 1

Does it clearly introduce the invention?

Good Fair Needs Revision

Comment:

Look at Paragraph 2

Is there a good Topic Sentence?

Good Fair Needs Revision

Comment:

Do all the other sentences support the Topic Sentence?

Good Fair Needs Revision

Comment:

Look at Paragraph 3

Is there a good Topic Sentence?

Good Fair Needs Revision

Comment:

Do all the other sentences support the Topic Sentence? Good Fair Needs Revision

Comment:

Is there a good Concluding Sentence?

Good Fair Needs Revision

Comment:

\section{Grammar, Vocabulary, and Spelling}

Read the essay again and look for grammar, vocabulary, punctuation, and spelling mistakes. Ask for help if you need it. Make some corrections on your classmate's paper.

Please write any other comments about your partner's essay. 


\section{Appendix D \\ Teacher Survey \\ Peer Review Teacher's Survey 2013}

Demographics: Please circle the number.

1. At this university, do you teach:
1 - Part-Time
2 - Full-Time

2. Are you:

1 - Japanese $\quad 2$ - Foreign

3. Which department(s) do you teach English courses in at this university?

Circle all that apply.

1 - Economics

3 - Information Sciences and Engineering

2 - Business Administration

5 - Life Sciences and Pharmaceutical Sciences

4 - Science and Engineering

6 - Sport and Health Science

\section{$1^{\text {st }}$ Year UI \& IM Students' Attitudes}

- Do you teach $1^{\text {st }}$ year upper-intermediate and / or intermediate level English classes at this university?

$$
1 \text { - Yes } 2-\text { No }
$$

- If Yes, please answer the 8 questions.

Instructions: Please answer these 8 questions based on your intuition and observations of your $1^{\text {st }}$ year upper-intermediate and/or intermediate level students. Circle the number that best corresponds to your agreement with the statement.

\begin{tabular}{|c|c|c|c|c|c|}
\hline $\begin{array}{c}1 \\
\text { Strongly } \\
\text { disagree }\end{array}$ & $\begin{array}{c}2 \\
\text { Disagree }\end{array}$ & $\begin{array}{c}3 \\
\text { Somewhat } \\
\text { disagree }\end{array}$ & $\begin{array}{c}4 \\
\text { Somewhat } \\
\text { agree }\end{array}$ & $\begin{array}{c}5 \\
\text { Agree }\end{array}$ & $\begin{array}{c}6 \\
\text { Strongly agree }\end{array}$ \\
\hline
\end{tabular}

1. My students enjoy writing in English.

$\begin{array}{llllll}1 & 2 & 3 & 4 & 5 & 6\end{array}$

2. Writing comments on classmates' work is NOT a problem for my students.
1
2
3
4
5
6

3. My students want to show their written work to their classmates.
1
2
3
4
5
6

4. My students want to read their classmates' work.
1
2
4
5
6

5. My students' English level is good enough to help their classmates improve their writing.
1
2
3
4
5
6

6. My students feel uncomfortable writing on their classmates' work.
1
2
3
4
5
6

7. My students believe that negative feedback helps them improve their work.
1
2
3
4
5
6

8. My students believe that positive feedback helps them improve their work.
1
2
3
4
5
6 


\section{Appendix E Student Consent Form}

Dear student,

As well as teaching English classes I am also part of a research group that is studying the best way to conduct Peer Review in English classes for university students in Japan. We are interested in how Japanese students change their writing during the drafting process. We would like to ask you for your help to collect data. We would like you to do two short questionnaires. We also want to use the drafts and peer review forms from your writing tasks. We plan to analyse your data to find out what students think about Peer Review and how to best use it in writing classes.

Please read the section below carefully, and if you agree to participate please sign below. If you do not want to participate then it will not affect your evaluation for this class at all - we will not use your data for our research.

In the future parts of this research may be published, but no real names will be used and your anonymity will be protected. If you have any questions please ask us.

Thank you for your help,

Bjorn Fuisting, Brett Morgan, and Jeremy White

Participant consent form

$\square$ I have read, and I fully understand, the description of the research to be carried out by Bjorn Fuisting, Brett Morgan, and Jeremy White.

$\square$ I understand that the questionnaires, writing drafts, and peer review forms will be used for data analysis.

$\square$ I understand that my real name will not be used in any documents and my identity will be kept secret.

I agree to take part in this study.

Signature

Date 
学生のみなさんへ

私は英語授業を担当するのに加え、日本の大学生向けの英語授業において、ピアレビュー の効果を研究するグループの一員でもあります。このグループでは、日本人学生のライティ ング力の変化に着目し、研究を進めています。研究に必要なデータを収集する上で、2つの アンケートとライティング課題のピアレビューフォームを使用させていただきたく、みなさ んにご協力を打願い申し上げます。収集したデータをもとに、みなさんのピアレビューに関 する考えを分析し、今後のライティング授業でどう役立てるか、検討する予定です。

つきましては、以下の項目を熟読いただき、ご協力いただける場合は、下記ボックスにチ エックの上、署名をお願い致します。ご協力いただけない場合、我々の研究材料としては、 一切使用致しません。なお、協力の有無に関わらず、授業評価の対象とは致しません。

また、今後、本研究内容が雑誌に掲載されたり、出版されることがあっても、皆さんの氏 名を公表することはなく、匿名を使用致します。ご不明な点等につきましてはご質問くださ い。

ご協力、ありがとうございます。

フースティング ビヨーン、モーガン ブレット、ホワイト ジェレミー

同意事項

口 上記内容を読み、フースティング ビヨーン、モーガン ブレット、ホワイト ジ エレミーによる研究内容について、理解しました。

ロ アンケート、ライティング課題、ピアレビューフォームを研究データとして使用す ることについて、理解しました。

ロどの研究資料にも氏名は使用せず、個人情報の保持に努めることについて、理解し ました。

上記、同意致します。

署名

日付 年 月 日 


\section{Appendix F \\ Demographic Characteristics Tables}

\section{Table F1}

\section{Demographic Characteristics of the Student Sample}

Characteristics

$\begin{array}{lrr}\text { Gender } & N & \% \\ \quad \text { Male } & 91 & 72.8 \% \\ \text { Female } & 34 & 27.2 \% \\ \text { Department } & & \\ \quad \text { Business Administration } & 61 & 48.8 \% \\ \text { Information Science and Engineering } & 64 & 51.2 \% \\ \text { Prior experience with peer review in Japanese } & & \\ \text { Yes } & 40 & 32 \% \\ \quad \text { No } & 84 & 67.2 \% \\ \quad \text { No response } & 1 & 0.8 \% \\ \text { Prior experience with peer review in English } & & \\ \text { Yes } & 7 & 5.6 \% \\ \text { No } & 117 & 93.6 \% \\ \text { No response } & 1 & 0.8 \% \\ \text { Lived abroad for longer than six months } & & \\ \text { Yes } & 9 & 7.2 \% \\ \text { No } & 116 & 92.8 \%\end{array}$

\section{Table F2}

\section{Demographic Characteristics of the Teacher Sample}

Characteristics

$\begin{array}{lrc}\text { Position } & n & \% \\ \text { Part-Time } & 8 & 22.22 \% \\ \text { Full-Time } & 28 & 77.77 \% \\ \text { Nationality } & & \\ \quad \text { Japanese } & 11 & 30.55 \% \\ \text { Foreign } & 25 & 69.44 \% \\ & & \\ \text { Department } & & \\ \text { Economics } & 17 & \\ \text { Business Administration } & 21 & \\ \text { Information Science and Engineering } & 4 & \\ \text { Science and Engineering } & 12 & \end{array}$

Note. As some instructors teach in multiple departments, no percentages were calculated for this section. 
Appendix G

T-test Table

\section{Table G1}

T-test Pre-Activity and Post-Activity Survey Q1-9

\begin{tabular}{|l|l|}
\hline$Q$ & $t$-test \\
\hline 1 & $t(124)=3.813, p<.01$ \\
\hline 2 & $t(124)=1.646, p=.102$ N.S. \\
\hline 3 & $t(124)=3.853, p<.01$ \\
\hline 4 & $t(124)=1.864, p=.065$ N.S. \\
\hline 5 & $t(124)=4.556, p<.01$ \\
\hline 6 & $t(124)=1.260, p=.210$ N.S. \\
\hline 7 & $t(124)=2.722, p=.007$ \\
\hline 8 & $t(124)=3.366, p=.001$ \\
\hline 9 & $t(123)=2.488, p=.014$ \\
\hline
\end{tabular}

